\title{
KOULUTUKSEN JA YHTEISKUNNAN REUNALLA
}

$\mathrm{J}$ oensuun yliopistossa järjestettiin toukokuussa kansainvälinen konferenssi At the MarJärjestäjinä toimivat sosiologian laitos ja monitieteinen koulutuksen yhteiskunnallis-kulttuurisen tutkimuksen yksikkö yhteistyössä Kansainvälisen sosiologiliiton (ISA) kasvatussosiologian ryhmän, Euroopan aikuiskasvatuksen tutkijain järjestön (ESREA) kahden tutkijaverkon sekä eurooppalaisen Ammattikasvatus ja kulttuuri -tutkijaverkon kanssa.

Konferenssiin ilmoittautui sata osanottajaa eri puolilta maailmaa, joista noin seitsemänkymmentä osallistui konferenssin istuntoihin. Ryhmistä mainittakoon eteläafrikkalaisen KwaZulu-Natalin yliopiston tutkijat, Taiwanin kansallisen yliopiston tutkijat ja Edinburghin yliopiston tutkijat Skotlannista.

Tulkitsen yleisesitelmien sanomaa seuraavasti. Tohtori Lawrence Saha Australian kansallisesta yliopistosta käsitteli aktiivista kansalaisuutta. Hän totesi, että jo Immanuel Kant liitti kansalaisuuden määritelmään aktiivisuuden. Passiiviset eivät Kantille oikeastaan olleet kansalaisia. Australiassa äänestäminen on pakollinen. Kuitenkin varsin suuri osa väestöstä, mm. 300000 nuorta ei äänestä. Hän ei pääesitelmässään etsinyt tälle selitystä, mutta toki me tiedämme, että politiikka koetaan nykymaailmassa varsin voimattomana talouteen verrattuna. Poliittisella kansalaisuudella ei enää ole sitä painoarvoa kuin ennen.

Professori Agnieszka Bron Tukholman yliopistosta puhui maahanmuuttajista kansalaisyhteiskunnan jäseninä. Hän mm. peräänkuulutti maahanmuuttajien kulttuurisen kansalaisuuden tärkeyttä. Siinä tulisi olla sijaa myös aikuiskoulutukseen osallistumiselle ja erityisesti uuden maan kielen oppimiselle. Hänen mielestään taloudellisen tuen antaminen ei ole riittävä eikä ehkä yhtä tärkeäkään kulttuurisen kansalaisuuden edellytys kuin edellä viittaamieni koulutusmahdollisuuksien järjestäminen.

Professori Carlos Torres UCLA:sta käsitteli globalisaation muotoja. Hän katsoi, että marginaalisuutta tarkastelemalla voitaisiin itse asiassa rakentaa yhteiskunnallisesti oikeudenmukaisen oppimisen teoriaa, malleja ja käytäntöä. ”Social justice learning”, jonka edellä käänsin yhteiskunnallisesti oikeudenmukaiseksi oppimiseksi, on eräs kansainvälisen koulutustutkimuksen laajenevia aloja.

Tohtori Ian Martin Edinburghin yliopistosta katsoi yhden aikuiskoulutuksen muodon ja aikuiskouluttajien ryhmän marginalisoituneen aikuiskoulutuksen muodonmuutoksessa. Tämä ryhmä on perinteisen vapaan sivistystyön edustajat. Marginalisoitumisen uutta tutkimusta hän kutsui Raymond Williamsiin viitaten eriytyneiden paradigmojen tutkimukseksi. Yhteiskuntaluokkaan, ikään, sukupuoleen, seksuaaliseen suuntautumiseen, rotuun ja vammaisuuteen kohdistuvat tutkimuksen ovat paljolti eriytyneet toisistaan.

Professori Kjell Rubenson Brittiläisen Kolumbian yliopistosta Kanadasta ja Linköpingin yliopistosta käsitteli osallistumattomuutta kansainvälisten vertailujen valossa. Hän totesi, että Pohjoismaissa osallistumisen taso on muuta maailmaa korkeampi. Tämän hän katsoi perustuvan pohjoismaiseen hyvinvointivaltioon, joka tässä tai tässäkin suhteessa eroaa anglosaksisesta ja mannereurooppalaisesta hyvinvointivaltion mallista. Kansalaisyhteiskunnan, työn ja perheen suhteet rakentuvat Pohjoismaisessa mallissa toisella tavoin aikuiskoulutusta tukeviksi kuin muissa hyvinvointivaltion malleissa. Hän kuitenkin raportoi vuonna 2003 kerätyn OECD:n lukutaitotutkimuksen alustavista tuloksista, joiden mukaan muut maat olisivat kuroneet kiinni Pohjoismaiden kaulaa. Suomi ei ole osallistunut tähän tutkimukseen.

Professori Knud Illeris Tanskan pedagogisesta yliopistosta on juuri päättänyt laajan tutkimuksensa matalan koulutuksen ja osaamisen ryhmien osallistumisesta aikuisopiskeluun. Hänen mukaansa näiden ryhmien jäsenet eivät toivo mitään enemmän kuin vakituista työpaikkaa. He ovat kuitenkin ambivalentteja eli epävarmoja ja ristiriitaisia suhtautumisessaan aikuiskoulutukseen. Hyvinkin pienet asiat aikuiskouluttajien tai muiden portinvartija- ja toimijaryhmien suhtautumi- 
sessa ja teoissa voi kääntää heidän suhtautumisensa myönteiseksi tai kielteiseksi. Nämä ihmiset ovat haavoittuvia ja pelkäävät taas uutta epäonnistumista elämässään.

Itse esitin esityksessäni sellaisen olettamuksen, että osa väestöä ja erityisesti yrittäjiä ja työntekijöitä elää vielä teollista eikä informaatioaikaa. He puolustavat teollisen ajan identiteettiään. Pieni osa tätä puolustusta on vähäinen osallistuminen aikuiskoulutukseen.
Neljässä samanaikaisessa työryhmässä viitisenkymmentä tutkijaa alusti tutkimuksistaan seuraaviin teemoihin ryhmitettynä: monet marginaalit, osallistuminen/ei-osallistuminen, identiteetti ja kulttuuri, korkeakoulutus, politiikan vaihtoehdot, kansalaisyhteiskunta ja kansalaisuus, oppiminen ja työelämä ja digitaalinen jako.

Tietoja konferenssista sen nettisivuilla: http:/ /www.joensuu.fi/sosiologia/margins2005/

Ari Antikainen 